\author{
Aleksander Naumow \\ Uniwersytet Ca' Foscari w Wenecji \\ anaumow@unive.it
}

Data przesłania tekstu do redakcji: 27.08.2014

Data przyjęcia tekstu do druku: 20.10.2014

\title{
Modlitwy za Ukrainę i o pokój „w czas próby i rozdziału"
}

Abstract: Naumow Aleksander, Modlitwy za Ukrainę i o pokój „w czas próby i rozdzialu” (Prayers for Ukraine and Peace in the "Times of Tribulation and Division"). "Poznańskie Studia Slawistyczne" 10. Poznań 2016. Publishing House of the Poznań Society for the Advancement of the Arts and Sciences, pp. 197-211. ISSN 2084-3011.

Based upon web-published materials, the article analyzes the eulogies composed in the Church Slavonic and Ukrainian languages, which have arisen following Kiev's Maidan and its subsequent developments in the period December 2013 - December 2014. The texts under analysis come from Ukrainian Orthodox Church of the Moscow Patriarchate and from the Patriarchate of Moscow itself, from the Ukrainian Orthodox Church of the Kiev Patriarchate and some other texts. Initiatives from the laity are also taken in account (e.g. Ruslana Lyžyčko). The prayers under analysis show historical and political influences. In the Muscovite texts and in Patriarch Kirill's statements, the attempt to impose the idea of a Russian Commonwealth (Russkij mir) is quite evident. This idea is based upon the unity and brotherhood of a people united by the christening of the Prince St. Vladimir. There are also charges brought against Greek Catholics and non-canonical Churches. The texts composed in Ukraine are either more decisively patriotic and anti-muscovite, with statements backing the European project (the Kiev Patriarchate Ukrainian Orthodox Church), or more religious in general terms, with a plea for fundamental Christian values and declarations of loyalty towards the State (the Moscow Patriarchate Ukrainian Orthodox Church).

KeYwords: liturgical prayers; war; peace; Moscow Patriarchate; Ukrainian Orthodox Church; Ukrainian Orthodox Church of the Kiev Patriarchate

Po brutalnym rozpędzeniu rankiem 30 listopada 2013 roku gromadzących się od kilku dni na kijowskim Majdanie manifestantów ${ }^{1}$ wszystkie Cerkwie Ukrainy² zareagowały intensyfikacją modłów o pokój i ład wewnętrzny.

${ }^{1}$ Za początek ukraińskiej Rewolucji Godności przyjmuje się 21 listopada, ogłoszony dekretem prezydenta Petra Poroszenki z 13 listopada 2014 roku świętem państwowym (Dzień Godności i Wolności).

${ }^{2}$ Zajmujemy się tu przede wszystkim Ukraińską Cerkwią Prawosławną Patriarchatu Moskiewskiego (UCP PM) i Ukraińską Cerkwią Prawosławną Patriarchatu Kijowskiego (UCP PK), w mniejszym stopniu Ukraińską Cerkwią Greckokatolicką (UCGK). Natomiast 
Między grudniem 2013 a latem 2014 roku w różnych ośrodkach cerkiewnych (ale także w Kościele katolickim, kościołach protestanckich i niechrześcijańskich związkach wyznaniowych) pojawiło się kilkadziesiąt nowych czy uaktualnionych tekstów modlitewnych, przeznaczonych do publicznego i prywatnego wykorzystywania. Tworzenie i używanie tekstów było coraz częstsze wraz z rozwojem wydarzeń, szczególnie w odpowiedzi na krwawe zamieszki 18-20 lutego w Kijowie, na odsunięcie od władzy prezydenta Wiktora Janukowycza (22 lutego), kryzys krymski (koniec lutego i marzec) oraz separatystyczne decyzje Doniecka i Ługańska (Noworosja), które zaowocowały wojną domową i konfliktem zbrojnym z Federacją Rosyjską.

Po pierwszych starciach na Majdanie schorowany metropolita UCP PM Włodzimierz (Sabodan) polecił, by od niedzieli 1 grudnia każdego dnia bożonarodzeniowego postu we wszystkich świątyniach metropolii odprawiano specjalne nabożeństwo o rozkrzewienie miłości ${ }^{3}$. W sieci pojawiła się modlitwa Владыко Вседержителю, Святый Царю, призри с небесе..., autorstwa Jewłogija (Gutczenki), arcybiskupa sumskiego i achtyrskiego ${ }^{4}$. Modlitwa, która stała się niezwykle popularna we wszyst-

Ukraińska Autokefaliczna Cerkiew Prawosławna (UACP) walczy z wewnętrznym kryzysem i zachowuje się nad wyraz powściągliwie. Jeden z jej skłóconych hierarchów Igor (Isiczenko), „arcybiskup charkowski i połtawski”, w marcu tak określał pozycję Cerkwi: „Єдина серед релігійних організацій в Україні, УАПЦ усунулася від підтримки київського Майдану та схвалення євроінтеграційної стратегії розвитку України, досі стримується від осуду російської агресії. Наша Церква, яка завжди була натхненницею боротьби за самостійну Українську Державу, за справедливий суспільний устрій, фактично виступає поплічницею історичного ворога України. Це не лише дискредитує нас усіх в очах української громади, але й відштовхує від УАПЦ іiї паству, унеможливлює нові покликання до священства й монашества". Ігор, архиєп., Звернення архиєпископа Ігоря до галицьких єпархій УАПЦ, <http:/uapc.org.ua/zvernennya-arhyjepyskopa-ihorya-dohalytskyh-jeparhij-uapts-2014-03-03/>, 21.08.2014.

${ }^{3}$ Служба о умноженіи любве, umieszczana w większości rękopiśmiennych i drukowanych trebników, jest dostępna w Internecie pod wieloma adresami, np. <http://gennik.spb. $\mathrm{ru} /$ grafics/treby/chast_trebi/page.php? $\mathrm{p}=2 \& \mathrm{~cd}=\& \mathrm{k}=>, 17.08 .2014$. Większość tekstów tego nabożeństwa jest zawsze aktualna, wspomina się starożytnych chrześcijan i prosi o sposobność, by ich naśladować, przytacza się wszystkie motywy związane z miłowaniem Boga i bliźniego, nalega na usunięcie z serc i umysłów takich cech jak egoizm, nienawiść, zawiść, pieniactwo, niepowściągliwość, umiłowanie świata, złość, pycha, nikczemność, fałsz i błaga o zastąpienie ich cnotami etycznymi osadzonymi w boskich przykazaniach.

${ }^{4}$ Np. А. Рыбак, Молитва о мире на Украине, <www.logoslovo.ru/forum/all/topic_8845_12_57717/>, 22.08.2014. 
kich środowiskach, mówi, że „ludzie ziemi naszej - jeden wobec drugiego - zamyślają rzeczy podłe i złe", padają w niej słowa o wysuszonych brakiem miłości sercach, porośniętych ciernistymi krzewami egoizmu, o nienawiści, zawiści, złości, wrogości, fałszu jako przyczynie podziałów i waśni. Na 6 grudnia $^{5}$, a więc na dzień św. Mikołaja, jednego z najbardziej czczonych $\mathrm{w}$ prawosławiu świętych, przygotowano specjalny tekst do odprawienia modłów we wszystkich diecezjach UCP PM. Skonstruowane na bazie tradycyjnie używanego rytu nabożeństwo ma kilka nowych akcentów, zrozumiałych w aktualnej sytuacji geopolitycznej. Do zespołu tradycyjnych próśb (w tym także za państwo, władze, wojsko i bogobojny naród) dołączono kilkanaście nowych. Modły wznoszono za wszystkich prawosławnych chrześcijan, zamieszkujących państwo ukraińskie, proszono o ducha miłości do Boga i do bliźniego, ducha pokoju i braterstwa, o wykorzenienie ducha podłości i nienawiści, podkreślano za św. Pawłem, że prawdziwa wiara i miłość jest wolna od egoizmu, ,nie szuka swego, nie pamięta złego, wszystko przetrzyma" (1 Kor 13,5). W drugiej grupie próśb (po ewangelii) błagano Pana o ,uśmierzenie wszelkich podziałów pośród narodu naszego, wykorzenienie do cna ducha nienawiści i zemsty i otoczenie ludzi prawdziwą miłością braterską”, i o to, by „w czas próby i rozdziału" (в годину испьтания и распрей) Bóg nie pozwolił ludziom błąkać się (=błądzić) po ścieżkach swojej grzesznej woli, lecz skierował ich na drogę Jego woli, wolnej od wrogości i pragnienia podziału.

Wersety towarzyszące czytaniom oraz same czytania, podobnie jak troparion tonu $4^{6}$ i kontakion tonu $5^{7}$, są wzięte $\mathrm{z}$ obowiązującej praktyki liturgicznej (prokimen t. 7: Ps 17,2-3a.c, apostoł: 1 J 3,1,10-11,16,18; 4,9-11,20-21 albo 1 Kor 13,1-8a,13; 14,1a, alleluja: Ps 30,24a.b, ewangelia: J 13,34-35; 15,12-14) i stanowią ścisły kanon tekstów mówiących o roli miłości we wzajemnych relacjach z Bogiem i z innymi ludźmi. Jedynie w drugiej części wersetu ,na alleluja” brzmi Dawidowa przestroga, że Pan „odpłaca z nawiązką tym, którzy wyniośle postępują”. Na zakoń-

${ }^{5}$ Starego stylu, według nowego to 19 grudnia.

${ }^{6}$ Союзом любве апостоль Твоя связавый, Христе... Oprócz tego tekstu w nowym rycie spotyka się odmienny troparion w tymże tonie, proszący Ukrzyżowanego o zesłanie normalnego życia i uspokojenie zamętu: Образ любве на Кресте Своем миру явив, в мире, Владько..., <http://feoblago.com/news/53/68/700>, 17.08.2014.

${ }^{7}$ Пламенем любве к Тебе распали сердия нама, Христе Боже... 
czenie nabożeństwa celebrans (biskup) z wielką atencją wygłasza nową modlitwę (inc. O, святый Владыко и Господи, сокровище благих...). Włodzimierzowy chrzest uczynił z wszystkich „ludzi naszej ojczyzny” lud Boży, święty naród, który przyniósł Panu Bogu ofiarę w postaci różnorakich czynów chwalebnych swoich licznych świętych. W przeszłości Izrael wielokrotnie zasługiwał na karę i gniew Pana, ale uzyskiwał od Niego przebaczenie, więc korzystając z tego wzorca, teraz prosi się o zmiłowanie dla „narodów naszego państwa ukraińskiego”, by nie zostały rozdzielone przez konflikty (распри) i rozbraty (междуусобия). Program naprawy polegać miałby na odnowieniu przez Pana w sercach ludzi Jego największego przykazania - by miłować Boga i bliźniego swego jak siebie samego (Mt 22,35-40), zesłaniu na nich ducha pokuty i bojaźni Bożej, co skutkowałoby pozyskaniem miłosierdzia przynoszącego pokój i dostatek ${ }^{8}$.

W decydującym momencie przemian, w połowie lutego, również sam patriarchat moskiewski włączył się do modlitewnej akcji mającej na celu zaprowadzenie ładu na Ukrainie. Modły wyznaczono na 24 lutego. Metropolita (dziś petersburski) Warsonofij (Sudakow) rozesłał do wszystkich diecezji i parafii patriarchatu orędzie patriarchy Cyryla (Gundiajewa) ${ }^{9}$ oraz teksty do włączenia podczas niedzielnej liturgii św. i następnie do codziennego wykorzystywania ${ }^{10}$. W orędziu moskiewski patriarcha roztacza wizję „rosyjskiego commonwealthu” (русский мир), nazywa Kijów „miejscem narodzin wielkiej prawosławnej cywilizacji, która połączyła narody Świętej Rusi”, mówi, że cała wielonarodowa Cerkiew patriarchalna modli się o pokój na ziemi Ukrainy, dziękuje tym hierarchom, którzy nie ulegli nacjonalnym i politycznym emocjom i wzywa do modlitwy za zabitych i rannych. Załączone teksty liturgiczne to trzy nowe prośby na ektenii usilnej, modlitwa Всевынний Боже, Владыко и Содетелю

\footnotetext{
${ }^{8} \mathrm{~W}$ sieci pojawiła się też odmienna modlitwa, będąca wariantem tradycyjnego tekstu, stosowana na proskomidii, inc. Господи Иисусе Христе Боже наш, давый ученикам Твоим заповедь новую...

${ }^{9}$ Кирилл, патр., Обращение Святейшего Патриарха Кирилла к полноте Русской Православной Церкви в связи с событиями на Украине, <http://www.patriarchia.ru/db/ text/3575247.html>, 17.08.2014.

${ }^{10}$ Циркуляр в епархии всей полноты Русской Православной Церкви. Особые прошения о мире на Украине на Божественной литургии 23 февраля 2014 года, <http:// www.patriarchia.ru/db/text/3575275.html>, 17.08.2014.
} 
всея твари... i jedna prośba na panichidzie nakazanej do odprawienia za poległych w konflikcie. W wezwaniach używa się ogólnego określenia „ziemia ukraińska”, prosi się Pana, by zesłał światło swojej mądrości na pogrążonych w mroku ludzi, którzy powodują, że szerzy się nienawiść, wrogość, krzywdy, korupcja (мздоимство), przelewanie krwi i inne przestępstwa. Wezwanie na nabożeństwie żałobnym dotyczy zabitych „w bratobójczym zamęcie na Ukrainie” (в братоубийственной смуте на Украине убиенных). Ta pierwsza modlitwa ułożona w patriarchacie jest bardzo ostrożna, operuje ogólnikami, prosi o pomoc dla wiernych w „kraju ukraińskim” prześladowanych przez zaślepionych, miłujących waśnie i konflikty. Modlitwę zanosi przed Pana Cerkiew Ruska, licząc na wstawiennictwo Matki Bożej, od zawsze pomagającej „krajom naszym".

Tydzień później, w Niedzielę przebaczenia win, patriarcha zwrócił się do kleru UCP MP z orędziem, stanowiącym dalszy komentarz do rozesłanych tekstów liturgicznych. Czytamy tam m.in.:

Krew naszych współbraci, przelana w Kijowie i innych miastach Ukrainy to owoc nienawiści, na wyhodowanie której w swoich sercach pozwolili nieprzyjacielowi rodzaju ludzkiego wszyscy uczestnicy konfliktu (противостояния). Niech Pan zatrzyma każdą rękę, podniesioną dla zadania bólu i cierpienia i niech błogosławi tym, co bronią pokoju. [...] Naród ukraiński powinien sam, bez zewnętrznych wpływów, określić swoją przyszłość. Braterstwo narodów rosyjskiego, ukraińskiego i białoruskiego to rzeczywistość, zrealizowana cierpieniami w historii przez wiele pokoleń naszych przodków i nie wolno jej składać w ofierze doraźnych interesów ${ }^{11}$.

Na Synodzie Biskupów PM, który odbył się 19 marca 2014 roku, m.in. przyjęto oświadczenie w sprawie Ukrainy. Użyto tam określeń „,narody Świętej Rusi” i „narody historycznej Rusi”, wskazując na niezniszczalny status baptyzmalnej więzi, gwarantującej jedność wiary i braterstwo ludzi ponad politycznymi i państwowymi podziałami ${ }^{12}$. Jest to pewna

${ }^{11}$ Кирилл, патр., Обращение Святейтего Патриарха Московского и всея Руси Кирилла к местоблюстителю Киевской митрополичьей кафедры митрополиту Черновиикому и Буковинскому Онуфрию, архипастырям, пастырям и всем верным чадам Украинской Православной Церкви в связи с ситуацией на Украине, 2 марта 2014 года, $<$ http://www.patriarchia.ru/db/text/3588256.html>, 17.08.2014. Przekład mój - A.N.

12 Заявление Священного Синода Русской Православной Церкви, <http://www.patriarchia.ru/db/text/3609033.html>, 22.08.2014. 
modyfikacja, przynajmniej terminologiczna, ideologemu „русский мир”, który wyraźnie nie sprawdził się już w praktyce. Wydaje się jednak, że te dwa terminy weszły na stałe do leksyki patriarchatu ${ }^{13}$.

Ważnym wydarzeniem było osobiste wygłoszenie lutowej modlitwy przez patriarchę w Wielką Sobotę 19 kwietnia ${ }^{14}$. Przed modlitwą hierarcha wygłosił mowę, w której przede wszystkim wskazał na dwie płaszczyzny istnienia Ukrainy, ale też przedstawił własną wizję dziejów:

Ukraina w planie politycznym jest państwem za granicą, ale w planie duchowym i historycznie to nigdy nie miało miejsca. My przed Bogiem jesteśmy jednym narodem, wyznajemy jedną wiarę prawosławną, mimo że są tacy, co chcą powiedzieć, że naród ukraiński wyznaje też inne wiary. My z szacunkiem traktujemy mniejszości religijne, ale niezmiennie będziemy twierdzić, że Ukraina, organicznie związana ze Świętą Rusią, jest krajem prawosławnym. (...) Dzisiaj musimy pomodlić się za naród Rusi, żyjący na Ukrainie, żeby Pan zesłał pokój na ziemię ukraińską, żeby nie dopuścił w żadnym wypadku do bratobójczej walki, zarówno wewnątrz państwa ukraińskiego, jak też wzajemnie między Ukrainą i Rosją, żeby pohamował zapędy tych, którzy chcieliby zabiegami politycznymi czy presją siłową rozerwać Świętą Ruś. Tak było nieraz w historii, ale tego nigdy i nikomu nie udało się dokonać ${ }^{15}$.

Modlitwa wygłoszona została na kolanach, hierarcha tłumaczył naruszenie przepisów liturgicznych wagą wydarzeń. Czytając tekst, dokonał dwóch istotnych zmian - po słowach „Молит Тя Церковь Русская” dodał ich własną interpretację - „Церковь Святой Руси духовно неразделимой”, a w miejsce określenia obiektu troski Matki Bożej, brzmiącego w pierwotnej wersji jako „страны наша”, wstawił termin „Русь Святую”.

Patriarcha 17 czerwca rozesłał nową modlitwę na liturgie ${ }^{16}$. Tu już otwarcie mówi się o walce wewnętrznej, przelewie krwi, klęskach spo-

${ }^{13}$ „И не исключено, что целясь в этот храм, они целились во всех нас, во всю Русь Святую, во всю Русь историческую, в которую многократно целились на протяжении всей нашей истории". Кирилл, патр., Я не верю, что снаряд был сброшен на храм случайно, <http://www.pravmir.ru/patriarh-kiriil-ya-ne-veryu-chto-snaryad-byil-sbroshen-na-hramsluchayno/>, 24.08.2014.

${ }^{14}$ Кирил, патр., Святейший Патриарх Кирилл в преддверии праздника Святой Пасхи совершил молитву об Украине, <http://www.patriarchia.ru/db/text/3630283.html>, 17.08.2014.

${ }^{15} \mathrm{Ibidem}$.

${ }^{16}$ Молитва о прекращениимеждоусобныя бранина Божественнойлитургии по сугубой ектении чтомая, <http://www.pravmir.ru/molitva-o-prekrashhenii-mezhdousobnyiya- 
łecznych, o ludziach pozbawionych dachów nad głową, głodnych, płaczących, rozłączonych... Winni tego stanu są pobratymcy (сродникu), którzy mają zatwardziałe serca i oddalili się od poznania woli Bożej. W miarę rozwoju konfliktu, w połowie sierpnia, już po wyborze nowego metropolity Onufrego (Berezowśkiego) na stolicę kijowską (13 sierpnia), ale przed jego intronizacją (17 sierpnia), patriarcha Cyryl zwrócił się z wezwaniem do głów kanonicznych Cerkwi prawosławnych, prosząc ich o współdziałanie w ratowaniu UCP MP przed niszczycielską działalnością nieprzyjaciół, tym razem, zgodnie z przekonaniem Moskwy o religijnym podłożu konfliktu ukraińskiego, nazwanych już po imieniu, czyli grekokatolików i dołączających do nich odszczepieńców $(\text { раскольники })^{17}$. Dzień po intronizacji metropolity Onufrego patriacha Cyryl wystąpił z analogicznym apelem do ONZ, Rady Europy i OBWE ${ }^{18}$. Inny charakter nosi natomiast apel Synodu Biskupów UCP PM z 13 lipca ${ }^{19}$, w którym hierarchowie wzywają przywódców krajów świata i wszystkich ludzi dobrej woli do wspólnych działań na rzecz zachowania status quo ,jedynej połączonej Ukrainy” (Сдина Соборна Україна) oraz deklarują gotowość do dalszych rozmów z UCP PK i UACP, przy

brani-na-bozhestvennoy-liturgii-po-suguboy-ektenii-chtomaya/\#ixzz3 Ae8PmWhI>, 17.08.2014.

${ }^{17}$ Czytamy między innymi: „C началом же боевых действий униаты и раскольники, получив в руки оружие, под видом антитеррористической операции стали осуществлять прямую агрессию в отношении духовенства канонической Украинской Православной Церкви на востоке страны”. Кирилл патр., Послание Патриарха Кирилла (Гундяева) Патриарху Константинопольскому Варфоломею", <http:/www.portal-credo.ru/site/index?act=news\&id=109244\&cf $=>, 17.08 .2014$. Pozostaje to $\mathrm{w}$ związku z orędziem spotkania Zwierzchników Lokalnych Cerkwi Prawosławnych, które w dniach 6-9 marca odbyło się w Stambule, w którym to orędziu na wniosek Moskwy wezwano do pokoju na Ukrainie i do powrotu „odszczepieńców” do kanonicznego prawosławia (punkt 3). Послание Предстоятелей Православных Церквей (6-9 марта 2014 года, Фанар), <http://www. patriarchia.ru/db/text/3599975.html>, 21.08.2014.

${ }^{18}$ Предстоятель Русской Православной Церкви обратился в ООН, Совет Европьл и ОБСЕ с письмом о фактах притеснения Украинской Православной Церкви в условиях вооруженного конфликта на юго-востоке Украинь, $<\mathrm{http}$ :/www.patriarchia.ru/db/ text/3706179.html>, 20.08.2014.

${ }^{19}$ Онуфрій, митр., Послання Собору Єпископів УПЦ до духовенства, чернецтва та усіх вірних Української Православної Церкви, <http://news.church.ua/2014/08/14/poslannya-soboru-jepiskopiv-ukrajinskoji-pravoslavnoji-cerkvi-do-duxovenstva-chernectva-tausix-virnix-ukrajinskoji-pravoslavnoji-cerkvi/>, 18.08.2014. 
czym dialog ten ma się odbywać na bazie kanonów prawosławia i bez ingerencji sił politycznych.

Paralelnie do liturgiczno-strategicznej działalności patriarchatu rozwija się działalność świeckich wiernych, a szczególne znaczenie ma tu autorytatywny niezależny portal moskiewski < pravmir.ru $>^{20}$. W samym końcu grudnia 2013 roku opublikował on w sieci zestaw modlitw o wzajemną miłość do stosowania poza publicznymi nabożeństwami ${ }^{21}$. Oprócz klasycznych hymnów umieszczono tam pięć modlitw: do św. Jana Ewangelisty, do św. Serafina z Sarowa, św. Sylwana z Athosu i dwie do Matki Boskiej, czczonej w dwu ikonach: Miłująca (Умиление) i Skruszenie złych serc (Умягчение зльх сердеи). W modlitwach tych brak bezpośrednich odwołań do sytuacji w regionie, przywołuje się tradycyjne funkcje świętych i Matki Bożej. W modlitwie do Jana przytacza się zwykłe problemy i możliwe nieszczęścia, znane z codziennych modlitw mszalnych, prosząc go o ochronę całego świata chrześcijańskiego. Jako zagrożenia, będące wynikiem sprawiedliwego gniewu Pana, wymienia się głód, zatracenie/zarazę/epidemię (cs. губительство), trzęsienie ziemi, powódź/potop, ogień, miecz, napaść obcych i rozbrat/walkę wewnętrzną (cs. междоусобная брань). Modlitwa do ulubieńca Rosjan św. Serafina jest bardziej pochwałą jego samego niż inwokacją o zwiększenie miłości. Więcej konkretów przynosi modlitwa do św. Sylwana, rosyjskiego mnicha wsławionego na Athosie, wezwanego przez Pana Boga do modlenia się za umarłych, żyjących i mających się narodzić. Modlitwa wzywa go, by wszystkim narodom świata wyprosił „długotrwałe i spokojne życie, ducha mądrej pokory i braterskiej miłości, cnoty i pragnienia zbawienia, ducha bojaźni Bożej, ażeby podłość i nieprawość nie zatwardzały serc człowieczych, niwecząc w ludziach miłość Bożą, wpędzając ich w niemiłą Bogu wrogość i bratobójstwo". Dzięki jego wstawiennictwu na Ziemi może zapanować pokój i Królestwo Boże. Pomoc świętego powinna objąć także jego ziemską ojczyznę - ziemię rosyjską, zapewniając jej „upragniony pokój i niebieskie błogosławieństwo".

${ }^{20}$ Pełna nazwa zasłużonego portalu: Православие и мир.

${ }^{21}$ Молитвы о умножении любви и искоренении ненависти и всякой злобы, $<$ http://www.pravmir.ru/molitvy-o-umnozhenii-lyubvi-i-iskorenenii-nenavisti-i-vsyakojzloby/\#ixzz3CEt6YZ15>, 17.08.2014. 
W maju 2014 roku w obliczu rosnącego przelewu krwi redakcja portalu dołączyła kolejne dwa teksty liturgiczne ${ }^{22}$.W prośbie przewidzianej na ektenii usilnej wymienia się szereg tradycyjnych przyczyn konfliktu w państwie i podaje do odmawiania modlitwę arcybiskupa Jewłogija. Na początku lipca portal opublikował obszerne nabożeństwo o pokój do domowego wykorzystywania (bez kapłana) ${ }^{23}$. Jego autorką jest Helena Wiktorowna Trostnikowa. Kompozycję oparła na praktyce liturgicznej wybitnego hierarchy i liturgisty rosyjskiego św. Afanasija (Sacharowa), biskupa kowrowskiego ${ }^{24}$, włączając do niej wszystkie moskiewskie teksty, powstałe z okazji wydarzeń na Ukrainie. Jak pisze sama autorka, ułożony tekst skonsultowała z byłą redaktor wydawnictwa patriarchatu Ludmiłą Pawłowną Miedwiediewą, która zasugerowała jej znaczące zmiany - zamianę określenia „земля Украинская” (które Trostnikowa początkowo wprowadziła, na miejsce „земля Русская” z tekstów św. Afanasija) na wyrażenia „Русь Святая” і „земля наша”, także „народ Руси святыя”, wszystko, zgodnie ze stanowiskiem patriarchy Cyryla, w liczbie pojedynczej, wprowadzając tym samym korektę ideologiczną, idącą w kierunku panrosyjskości. Tekst Trostnikowej jest przykładem wpisania nowej twórczości w żywą tradycję liturgiczną Cerkwi z uwzględnieniem aktualnej pozycji ideologicznej. W modlitwie, w której wymienia się świętych patronów i wstawienników, autorka uwzględniła kilkudziesięciu świętych, związanych w różny sposób z Ukrainą, wpisując ich w kontekst ogólnoruski ${ }^{25}$.

Teksty te w zasadzie zamknęły twórczość euchograficzną, związaną z wydarzeniami. Modły o pokój na Ukrainie i w sercach ludzi trwają nieustannie. $\mathrm{W}$ dniach, kiedy obchodzono w kraju rocznicę rozpoczęcia wydarzeń na Majdanie, metropolita kanonicznej UCP PM Onufry, zalecił

${ }^{22}$ Молитва о мире в Украине, <http://www.pravmir.ru/molitva-o-mire-v-ukraine/\# ixzz37B6o1tin>, 17.08.2014.

${ }^{23}$ Молитва об Украине: Призри на скорбь чад Твоих, в земли украинстей сущих, $<$ http://www.pravmir.ru/pomolimsya-ob-ukraine/\#ixzz37BWeXTju>, 21.08.2014.

${ }^{24}$ Последования молебных пений на различные потребы, <http://www.svt-afanasiy. narod.ru/penpotr.htm>, 20.08.2014. Chodzi szczególnie o nabożeństwa błagalne: o rozkrzewienie miłości, wykorzenienie nienawiści i złości, za wrogów i tych, co nas nienawidzą, na czas wojny, w czasie nadejścia barbarzyńców, o ustanie wojen i pokój na całym świecie, za Kraj (z sierpnia 1941 roku) i analogiczne (об Отечестве) ułożone specjalnie dla laików.

${ }^{25}$ Święci ci z datami obchodu zostali wskazani także osobno po tekście nabożeństwa jako wstawiennicy, do których trzeba się zwracać w związku z sytuacją na Ukrainie. 
wszystkim wiernym modły przed ikonami Matki Boskiej. W udzielonym wywiadzie powiedział:

Podczas tych dni wszyscy błagamy Matkę Bożą, by orędowała za nami przed Panem, Zbawcą naszego świata, by ludzie zaniechali wzajemnej wrogości i by Bóg odpuścił nam nasze grzechy, które są przyczyną waśni w społeczeństwie. Wiadomo, że wojuje ten, w czyjej duszy nie ma spokoju. Kiedy dusza jest przepełniona złością (злоба), to ona z niej tryska i może się rozlać w bratobójczą wojnę. Modlimy się do Matki Bożej, by ugasiła te problemy w naszym Państwie, by zesłała pokój naszemu narodowi, naszym rodzinom i ludzkim sercom ${ }^{26}$.

W odróżnieniu od Cerkwi pozostającej w strukturach patriarchatu moskiewskiego niekanoniczna Cerkiew Patriarchatu Kijowskiego, nastawiona proukraińsko i proeuropejsko, w obliczu konfliktu przemawia jednym głosem z wyraźnie antymoskiewską nutką, otwarcie mówiąc o wojnie z zewnętrznym agresorem i o wewnętrznych zdrajcach judaszach. Już kilka dni po krwawych zamieszkach z 18-20 lutego Rada Wydawnicza UCP KP podjęła uchwałę o wydaniu zbioru modlitw za Ukrainę i o pokój. Sześćdziesięciostronicowa broszura ukazała się w kwietniu z błogosławieństwa patriarchy Filareta (Denysenki) w wydawnictwie podkijowskiej parafii św. Michała ${ }^{27}$, prowadzącej od lat bogaty portal internetowy. Zbiór składa się z dwóch części: Modlitw i Suplikacji (правила). Otwiera go Modlitwa za Ukraine - duchowy hymn (inc. Боже великий, єдиний, нам Україну храни...), który powstał w 1885 roku - muzyka: Mykołaj Łysenko do słów Ołeksandra Konyśkiego. W UCP KP i w UCGK jest zwyczaj wykonywania tego hymnu na zakończenie nabożeństw. Następnie mamy dwie nowe modlitwy ogólne, wykorzystywane później także w suplikacjach i kolejno modlitwy: za Cerkiew Ukraińską, do św. Hioba Poczajewskiego o pokój i pomyślność Państwa, o ratunek dla Państwa, uspokojenie w nim zamętu i wrogości, modlitwa autorstwa patriarchy

${ }^{26}$ На праздник Введения мы просим Богородииу чтобы она послала мир нашему народу - предстоятель УПЦ, < http://religions.unian.net/orthodoxy/1017644-na-prazdnikvvedeniya-myi-prosim-bogoroditsu-chtobyi-ona-poslala-mir-nashemu-narodu-predstoyatelupts.html>, 4.12.2014.

${ }^{27}$ Молитви за Україну та ї̈ захисників, Київ-Пирогів 2014, <http://www.parafia. org.ua/biblioteka/molytvy/molytvy-za-ukrajinu-ta-jiji-zahysnykiv/>, 20.08.2014. Dostępne w Internecie częściowo jako kontynuacja poprzednich wydań, <http://www.parafia.org.ua/ biblioteka/molytvy/molytvy-za-ukrayinu/>. Wszystkie wcześniejsze modlitwy zostały poddane aktualizacji i opublikowane 10-11 kwietnia 2014 roku. 
Filareta na czas wielkich konfliktów, na dni napaści wrogów na Państwo, krótka modlitwa w czasach nieszczęścia, modlitwa za nieprzyjaciół, do niebiańskich patronów ziemi ukraińskiej, pokutna modlitwa proroka Daniela, modlitwa dla żołnierzy i za żołnierzy. W drugiej części mamy bardziej rozbudowane (zwłaszcza o odpowiednie psalmy) ryty: o pokój w państwie, o jedność i natchnienie mądrością władz, o duchową równowagę w czasach klęski (лихоліття), na czas nieszczęścia i agresji, za obrońców ojczyzny i za naród w obliczu wielkiego niebezpieczeństwa, za jeńców i więźniów, o wybawienie z wielkiego zagrożenia - do codziennego odmawiania. Robi wrażenie wykorzystanie (w pewnym skrócie) starotestamentowej modlitwy pokutnej proroka Daniela (Dn 9,3-19), wskazującej na grzech własny i nieprawości jako praprzyczyny kary Bożej i wzywającej do pokładania całej ufności w miłosierdziu Bożym. Również wykaz świętych patronów i wstawienników jest ograniczony wyłącznie do osób ściśle związanych z Ukrainą i pozbawiony szerszego kontekstu ogólnoruskiego.

Oczywiście, przedstawiony tomik nie zawiera całej twórczości euchograficznej UCP KP. Warto zauważyć, że jedną z cech charakterystycznych jest odwoływanie się do tradycji metropolii kijowsko-halickiej XVI-XVII wieku, w tym przede wszystkim do Trebnika św. Piotra (Mohyły) z 1646 roku. Ciekawym tego przykładem jest modlitwa ${ }^{28}$, którą ułożył metropolita lwowski i sokalski Dymytrij (Rudiuk). Wykorzystał opracowany przez św. Piotra na bazie tradycji bizantyńsko-ruskiej i opublikowany w Trebni$k u$ ryt do odprawiania za „cesarza i za naród w czasie walki z wrogami” skonfrontowany z modłami ,,podczas napaści barbarzyńców i przy nadejściu pogan”, przerobił go nieznacznie i przetłumaczył na język ukraiński. Patriarcha Filaret zaakceptował nowy utwór i 14 marca zalecił do wykorzystywania w powszechnej praktyce liturgicznej kierowanej przez niego Cerkwi wraz z usilnymi prośbami o ratunek dla Ukrainy w obliczu obcej interwencji. Dwa tygodnie później ukazało się całe nabożeństwo o zwycięstwo nad wrogiem, w całości oparte na wspomnianym rycie Mohylańskiego Trebnika ${ }^{29}$, podobnie jak ryty święcenia broni, sztandarów czy udziela-

${ }^{28}$ Господи Боже сил, Боже спасіння нашого..., < $<$ http://www.cerkva.info/uk/news/patriarkh/4565-rozporiadzhennia.html>, 21.08.2014.

${ }^{29}$ МолебеньдоГосподаБогавчасівійнипроперемогунадворогом, $<$ http://kyiv-pravosl. 
nia błogosławieństwa żołnierzom posyłanym do walki z separatystami.W rocznicę tragicznych wydarzeń noc z 29 na 30 listopada 2014 roku została ogłoszona nocą pamięci, na Majdanie odbyło się całonocne czuwanie z paleniem zniczy. Rano w cerkwi monasteru św. Michała, który rok wcześniej udzielił schronienia atakowanej przez milicjantów z Berkutu młodzieży, rozpoczęły się obchody liturgiczne z udziałem prezydenta Petra Poroszenki z małżonką. O godz. 14.00, z inicjatywy patriarchy Filareta, w większości miast Ukrainy odbyły się modły o przywrócenie pokoju w kraju, centralne uroczystości miały miejsce właśnie na placu św. Michała, a głównym tekstem modlitewnym był Akatyst do Matki Boskiej Opiekuńczej (Pokrow). Oprócz patriarchy Filareta w modłach za Ukrainę wziął udział metropolita UCGK Światosław (Szewczuk). Następnie patriarcha Filaret kontynuował modły na placu przed Świętą Sofią. Program tych uroczystości spotkał się z emocjonalną krytyką moskiewskich obserwatorów ${ }^{30}$ i z bojkotem ze strony kanonicznej Cerkwi.

Natomiast Synod Biskupów UCGK 17 czerwca ogłosił kontynuację na swym terytorium cyklu modlitewnego i nieustającego ścisłego postu w intencji pokoju. Modlitwy zostały wyznaczone na godzinę 21.00 poszczególnych dni tygodnia. I tak, poniedziałek jest dniem modlitwy za Prezydenta, Rząd i Radę Najwyższą, wtorek za nieprzyjaciół, środa za ukraińską armię, czwartek za organa bezpieczeństwa publicznego i milicję, piątek za rannych, więzionych, uchodźców i ich rodziny, sobota za poległych i zabitych, niedziela za jedność i nierozłączność Ukrainy. Jednocześnie rozpisano ścisły post od poniedziałku do piątku, po jednym dniu na określoną strukturę Cerkwi ${ }^{31}$.

Modlitwy funkcjonują także w przestrzeni pozacerkiewnej. W maju i w lipcu 2014 roku piosenkarka i działaczka Rusłana Łyżyczko z przyjaciółmi zorganizowała niezwykle nagłośnioną i popularną akcję modłów ,za Ukrainę, o pokój i spokój”. Szczególnego charakteru nabrała manifestacja w przeddzień wyborów prezydenta, a w dzień św. św. Cyryla i Metodego.

info/2014/03/28/moleben-do-hospoda-boha-v-chasi-vijny-pro-peremohu-nad-vorohom/>, 20.08.2014.

${ }^{30}$ Украинские раскольники-филаретовцьы „благословляют” карателей, <http:// www.nakanune.ru/news /2014/ 11/ 29/22378705/\#sthash.46gK0084.dpuf>, 1.12.2014.

31 Заклик Синоду Спископів продовжувати безпереривну молитву $i$ піст за мир в Україні, еп. Святослав, <http://cerkiew.nazwa.pl/?p=5766>, 21.08.2014. 
W świątyniach różnych Cerkwi 23 maja odbyły się specjalne nabożeństwa wieczorne, a 24 maja w południe modlitewne spotkania. Centralne uroczystości, transmitowane w trzech językach - po ukraińsku, rosyjsku i angielsku - przez Internet, telewizję i radio, miały miejsce w południe na beskidzkiej przełęczy Chomiak (1542 m n.p.m.) w Gorganach, towarzyszyły im nieco mniejsze uroczystości w licznych miastach Ukrainy. Jednocześnie do akcji włączyli się chrześcijanie, przede wszystkim kolonie ukraińskie, w różnych miastach Europy, w tym w Warszawie, a kilka godzin później za oceanem w São Paolo, Nowym Jorku, Toronto i w innych miastach świata. Prowadzona przez popularną artystkę, powtarzana później w transmisjach telewizyjnych modlitwa nosi ekumeniczny i patriotyczny charakter, padają w niej prośby o pokój dla jedynej niepodzielnej Ukrainy, o uśmierzenie nienawiści, o braterską miłość, o wolność i niepodległość, o godność ludzką i obywatelską wraz ze słowami dziękczynienia i chwały. Łączy się ją stale $\mathrm{z}$ tradycyjnymi modlitwami do Matki Bożej ${ }^{32}$. Istnieją też inne zajmujące lokalne inicjatywy, jak np. wybudowanie w Charkowie przez młodzież w ciągu jednej doby 19-20 lipca świątyni, przeznaczonej do modlitw o pokój i ochronę miasta ${ }^{33}$. Należy zauważyć, że na internetowych blogach obok żywego uczestnictwa wyznawców różnych konfesji spotykamy często opinie negujące sens i moc sprawczą tych i takich modlitw, płynące zarówno z przekonań ateistycznych, jak i wywołane głębokim rozczarowaniem postawą duchowieństwa i szokiem w obliczu historycznej tragedii.

\section{Literatura}

В харьковской области построили «храм за один день», <http://www.pravoslavie. $\mathrm{ru} / \mathrm{news} / 72387 . \mathrm{htm}>, 21.08 .214$.

Господи Боже сил, Боже спасіння нашого..., <http://www.cerkva.info/uk/news/patriarkh/4565-rozporiadzhennia.html>, 21.08.2014.

Заклик Синоду Спископів продовжувати безпереривну молитву i nicm за мир в Україні, еп. Святослав, <http://cerkiew.nazwa.pl/?p=5766>, 21.08.2014.

\footnotetext{
32 Лижичко, Всесвітня Молитва за Україну, Мир та Спокій!, <http://blogs.pravda. com.ua/authors/ruslana/537f73032101b/>, 20.08.2014

${ }^{33}$ В харьковской области построили «храм за один день», <http://www.pravoslavie. $\mathrm{ru} / \mathrm{news} / 72387 . \mathrm{htm}>, 21.08 .214$.
} 
Заявление Священного Синода Русской Православной Церкви, <http://www.patriarchia.ru/db/text/3609033.html>, 22.08.2014.

Ігор, архиєп., Звернення архиєпископа Ігоря до галиизьких єпархій УАПЦ, $<$ http://uapc.org.ua/zvernennya-arhyjepyskopa-ihorya-do-halytskyh-jeparhijuapts-2014-03-03/>, 21.08.2014.

Кирилл, патр., Обращение Святейшего Патриарха Кирилла к полноте Русской Православной Церкви в связи с событиями на Украине, <http://www.patriarchia.ru/db/text/3575247.html>, 17.08.2014.

Кирилл, патр., Обращчение Святейшего Патриарха Московского и всея Руси КириллакместоблюстителюКиевскоймитрополичьейкафедрымитрополиту Черновиикому и Буковинскому Онуфрию, архипастырям, пастырям и всем верным чадам Украинской Православной Церкви в связи с ситуачией на Украине, 2 марта 2014 года, <http://www.patriarchia.ru/db/text/3588256.html>, 17.08.2014.

Кирилл, патр., Послание Патриарха Кирилла (Гундяева) Патриарху Константинопольскому Варфоломею, <http://www.portal-credo.ru/site/ index? act $=$ news\&id $=109244 \& \mathrm{cf}=>$, 17.08.2014.

Кирилл, патр., Святейший Патриарх Кирилл в преддверии праздника Святой Пасхи совершил молитву об Украине, <http:/www.patriarchia.ru/db/ text/3630283.html>, 17.08.2014.

Кирилл, патр., Я не верю, что снаряд был сброшен на храм случайно, <http:// www.pravmir.ru/patriarh-kiriil-ya-ne-veryu-chto-snaryad-byil-sbroshen-na-hramsluchayno/>, 24.08.2014.

Лижичко Р., Всесвітня Молитва за Украӥну, Мир та Спокій!, <http://blogs.pravda. com.ua/authors/ruslana/537f73032101b/>, 20.08.2014.

Молебень до Господа Бога в часі війни про перемогу над ворогом, <http://kyivpravosl.info/2014/03/28/moleben-do-hospoda-boha-v-chasi-vijny-pro-peremohunad-vorohom/>, 20.08.2014.

Молитва о мире в Украине, <http://www.pravmir.ru/molitva-o-mire-v-ukraine/\#ixzz 37B6oltin>, 17.08.2014.

Молитва о прекращении междоусобныя брани на Божественной литургии по сугубой ектении чтомая, <http:/www.pravmir.ru/molitva-o-prekrashheniimezhdousobnyiya-brani-na-bozhestvennoy-liturgii-po-suguboy-ekteniichtomaya/\#ixzz3Ae8PmWhI>, 17.08.2014.

Молитва об Украине: Призри на скорбь чад Твоих, в земли украинстей сущих, $<$ http://www.pravmir.ru/pomolimsya-ob-ukraine/\#ixzz37BWeXTju>, 21.08.2014.

Молитви за Україну та ї̈ захисників, Київ-Пирогів 2014, <http://www.parafia.org. ua/biblioteka/molytvy/molytvy-za-ukrajinu-ta-jiji-zahysnykiv/>, 20.08.2014.

Молитвы о умножении любви и искоренении ненависти и всякой злобы, <http:// www.pravmir.ru/molitvy-o-umnozhenii-lyubvi-i-iskorenenii-nenavisti-i-vsyakojzloby/\#ixzz3CEt6YZ15>, 17.08.2014.

На праздник Введения мы просим Богородииу чтобы она послала мир нашему народу-предстоятель УПЦ, < http://religions.unian.net/orthodoxy/1017644-na- 
prazdnik-vvedeniya-myi-prosim-bogoroditsu-chtobyi-ona-poslala-mir-nashemunarodu-predstoyatel-upts.html>, 4.12.2014.

Онуфрій, митр., Послання Собору Спископів УПЦ до духовенства, чернецтва та усіх вірних Украӥнської Православної Церкви, <http://news.church. ua/2014/08/14/poslannya-soboru-jepiskopiv-ukrajinskoji-pravoslavnoji-cerkvido-duxovenstva-chernectva-ta-usix-virnix-ukrajinskoji-pravoslavnoji-cerkvi/>, 18.08.2014.

Послание Предстоятелей Православных Церквей (6-9 марта 2014 года, Фанар), $<$ http://www.patriarchia.ru/db/text/3599975.html>, 21.08.2014.

Последования молебных пений на различные потребы, <http://www.svt-afanasiy. narod.ru/penpotr.htm>, 20.08.2014.

Предстоятель Русской Православной Церкви обратился в ООН, Совет Европь и ОБСЕ с письмом о фактах притеснения Украинской Православной Церкви в условиях вооруженного конфликта на юго-востоке Украины, $<\mathrm{http}: / / \mathrm{www}$. patriarchia.ru/db/text/3706179.html>, 20.08.2014.

Рыбак А., Молитва о мире на Украине, <www.logoslovo.ru/forum/all/topic_8845_12_57717/>, 22.08.2014.

Служба о умноженіи людве, <http://gennik.spb.ru/grafiks/treby/chast_trebi/page.php $? \mathrm{p}=2 \& \mathrm{~cd}=\& \mathrm{k}=>$.

Украинские раскольники-филаретовиь ,,благословляют " карателей, $<\mathrm{http}: / / \mathrm{www}$. nakanune.ru/news /2014/ 11/ 29/22378705/\#sthash.46gK0084.dpuf>, 01.12.2014.

Циркуляр в епархии всей полноты Русской Православной Церкви. Особые прошения о мире на Украине на Божественной литургии 23 февраля 2014 годa, <http://www.patriarchia.ru/db/text/3575275.html>, 17.08.2014. 